\title{
Gambaran Estimasi Usia Biologis dengan Menggunakan Metode Blenkin- Taylor (Modifikasi Sistem Demirjian) di Kota Semarang
}

\author{
Niluh R. Woroprobosari, Devina V. Wisaputri, Muhammad H. Ni'am
}

Fakultas Kedokteran Gigi Universitas Islam Sultan Agung, Semarang, Jawa Tengah, Indonesia Email: niluh.ringga@unissula.ac.id

\begin{abstract}
Unexpected incident such as natural disaster and accident often occur in many countries including Indonesia which causes many victims with unknown identity. Tooth is one of the indicators to assess and determine a person's identity. Blenkin-Taylor method is used for age estimation of an individual by using teeth. This study was aimed to obtain the estimation of biological age by using Blenkin-Taylor method in Semarang. This was a descriptive study with a cross sectional design. Samples were panoramic digital radiograph data of patients aged 5-15 years, copied in the form of a soft file. The observation and measurement were performed on seven teeth of right lower jaw by using the DICOM RadiAnt application. Data of observations and measurements of maturation scores were calculated and converted into the Blenkin-Taylor formula to determine the biological age. The results showed that the difference between biological and chronological age was \pm 0.32 years. This value was lower than the Blenkin-Taylor previous study result which was $\pm 0,6$ years. In conclusion, by using the Blenkin-Taylor method, there was a difference between biological age and chronological age as many as $\pm 0,32$ years in individuals aged 5-15 years old in Semarang.
\end{abstract}

Keywords: biological age, the Blenkin-Taylor method, panoramic radiography

\begin{abstract}
Abstrak: Kejadian tidak terduga seperti bencana alam dan kecelakaan sering terjadi di berbagai negara, salah satunya di Indonesia yang menimbulkan banyak korban jiwa yang tidak diketahui identitasnya. Gigi merupakan salah satu indikator untuk menilai dan menentukan identitas seseorang. Salah satu metode dalam menentukan estimasi usia dengan menggunakan gigi ialah metode Blenkin-Taylor. Penelitian ini bertujuan untuk mendapatkan gambaran estimasi usia biologis dengan menggunakan metode Blenkin-Taylor di Kota Semarang. Jenis penelitian ialah deskriptif dengan desain potong lintang. Sampel penelitian ialah data file digital radiograf panoramik pasien berusia 5-15 tahun yang disalin ke dalam bentuk soft file, kemudian dilakukan pengamatan dan pengukuran pada 7 gigi regio kanan rahang bawah dengan menggunakan aplikasi RadiAnt DICOM. Hasil pengamatan dan pengukuran skor maturasi dihitung dan dikonversikan ke dalam rumus metode Blenkin-Taylor untuk menentukan usia biologis. Hasil penelitian menunjukkan bahwa selisih usia biologis dan usia kronologis sebesar 0,32 tahun. Hal ini lebih kecil dibandingkan penelitian Blenkin-Taylor terdahulu sebesar 0,6 tahun. Simpulan penelitian ini ialah dengan mengggunakan metode Blenkin-Taylor terdapat selisih rerata usia kronologis dan usia biologis sebesar $\pm 0,32$ tahun pada individu usia 5-15 tahun di Kota Semarang.

Kata kunci: usia biologis, metode Blenkin-Taylor, radiograf panoramik
\end{abstract}

\section{PENDAHULUAN}

Identifikasi forensik merupakan upaya untuk mengetahui identitas seseorang yang diperoleh dari interpretasi hasil temuan dunia kedokteran. Penentuan identitas ini dapat dilakukan dengan membandingkan ciri khas yang didapat semasa hidup maupun setelah kematian. Identifikasi forensik dapat dilihat melalui identifikasi primer maupun identifikasi sekunder. Identifikasi primer meliputi tulang, gigi geligi, sidik jari, rambut, serta DNA. Identifikasi sekunder 
sebagai identitas pendukung yang berupa kartu tanda penduduk, surat ijin mengemudi dan sebagainya. ${ }^{1}$

Odontologi forensik adalah ilmu kedokteran gigi yang berkaitan dengan kepentingan hukum. Bidang Kedokteran Gigi melibatkan pengumpulan, pemeriksaan serta pemaparan benda bukti berupa gigi yang telah ditemukan; ${ }^{2}$ oleh karena itu, seorang dokter gigi mempunyai peran penting dalam melakukan identifikasi gigi.

Gigi merupakan salah satu jaringan keras dalam tubuh manusia yang memiliki kelebihan ditinjau dari sifatnya, yaitu tahan terhadap panas yang mencapai suhu $\pm 900^{\circ} \mathrm{C}$, tidak mudah rusak selama penyimpanan, dan melekat erat pada tulang rahang. Oleh sebab itu, gigi dijadikan sebagai salah satu indikator dalam menilai serta menentukan estimasi usia seseorang. ${ }^{3}$

Terdapat beberapa penelitian yang memiliki metode dan cara untuk memperkirakan usia seseorang berdasarkan perubahan anatomis, struktur gigi serta membandingkan gambaran radiografi panoramik gigi geligi dengan diagram perkembangan gigi. Schour-Massler (1941) menjelaskan bahwa estimasi usia dental terbagi dalam 21 tahap perkembangan dan melibatkan gigi sulung serta gigi geligi di rahang atas serta rahang bawah. Kendala pada metode Schour-Massler yaitu pada bagan perkembangan gigi tidak terdapat perbedaan antara jenis kelamin laki-laki dan wanita, ${ }^{4}$

Al-Qahtani menjelaskan perkembangan gigi dan tingkat erupsinya pada satu regio di rahang atas dan satu regio rahang bawah pada setiap individu dengan rentang usia 623 tahun. Kendala pada metode Al-Qahtani yaitu diagram metode Al-Qahtani hanya dilihat berdasarkan perkembangan gigi molar ke-dua dan ke-tiga saja, sehingga dapat memengaruhi hasil usia dari penelitian yang disebabkan oleh keadaan perkembangan gigi molar ke-tiga yang berbeda-beda. $^{5}$

Metode Blenkin-Taylor memiliki kelebihan yaitu dapat membedakan jenis kelamin laki-laki atau perempuan, serta perkembangan gigi yang diamati menggunakan tujuh gigi, sehingga metode Blenkin-
Taylor dapat mengakomodir kekurangan dari metode-metode sebelumnya. Mengingat pentingnya penentuan usia biologis termasuk kasus forensik dan medikolegal maka penulis tertarik untuk mengetahui gambaran estimasi usia biologis menggunakan metode Blenkin-Taylor di Kota Semarang.

\section{METODE PENELITIAN}

Penelitian ini dilakukan di Instalasi Radiologi RSIGM Sultan Agung, RSI Sultan Agung, RSUP Dr. Kariadi dan RS Tugurejo Semarang. Jenis penelitian ialah deskriptif dengan desain potong lintang. Instrumen yang digunakan pada pengukuran gigi yaitu file radiograf panoramik, aplikasi RadiANT DICOM Viewer dan tabel metode Demirjian. Sampel penelitian ialah 152 radiograf panoramik pasien dengan rentang usia 5-15 tahun, karena metode Blenkin-Taylor menunjukkan akurasi yang baik pada rentang usia tersebut. ${ }^{6,7}$

Data file digital radiograf panoramik dikumpulkan dalam format berdasarkan kriteria inklusi dan kriteria eksklusi. Data radiograf panoramik diambil dengan cara menyalin file digital radiograf panoramik dalam flashdisk dari server format JPG atau DICOM dan dibuka dengan aplikasi RadiANT DICOM. Penelitian dilakukan oleh 3 orang ( 2 orang peneliti dan 1 orang ahli radiografi) dan dilakukan uji reliabilitas antar rater dengan Interclass Correlation Coefficients (ICC). Berdasarkan hasil perhitungan didapatkan reliabilitas Alpha yang memuaskan yaitu 0,979. Berdasarkan hasil dari Interclass Correlation Coefficient (ICC) dan reliabilitas antar rater menunjukkan 0,941 dengan kategori "cukup memuaskan" sehingga penelitian ini sudah layak dilakukan karena persepsi antar peneliti sudah sama. Pengukuran dilakukan dengan menggunakan aplikasi RadiAnt DICOM.

Pengukuran data radiograf menggunakan gigi insisivus sentral, insisivus lateral, kaninus, premolar pertama, dan kedua, molar pertama juga kedua. regio kanan rahang bawah dari gambar tahapan pembentukan gigi oleh Demirjian. Hasil 
pengukuran dihitung semua skor untuk tiap gigi dijumlah dan dihitung skor maturasinya, lalu dikonversi langsung kedalam rumus yang berhubungan antara usia kronologis dan Simple Maturity Score (SMS). Pencatatan usia kronologis dilakukan sesuai data dari rekam medis. Data yang diperoleh selanjutnya dilakukan analisis statistik deskriptif yaitu dengan rerata dan simpangan baku. Penyajian data ditampilkan dalam bentuk tabel dan pie diagram.

Metode Blenkin-Taylor tersebut dimodifikasi dari metode Demirjian, sehingga pengukuran data radiografi menggunakan gigi insisivus sentral, insisivus lateral, kaninus, premolar pertama, premolar kedua, molar pertama, dan molar kedua regio kanan rahang bawah. Demirjian membuat delapan tahapan kalsifikasi gigi dan memberinya skor dari A hingga $\mathrm{H}$ (Tabel 1). ${ }^{6}$

Tabel 1. Tahapan pembentukan gigi oleh Demirjian $^{6}$

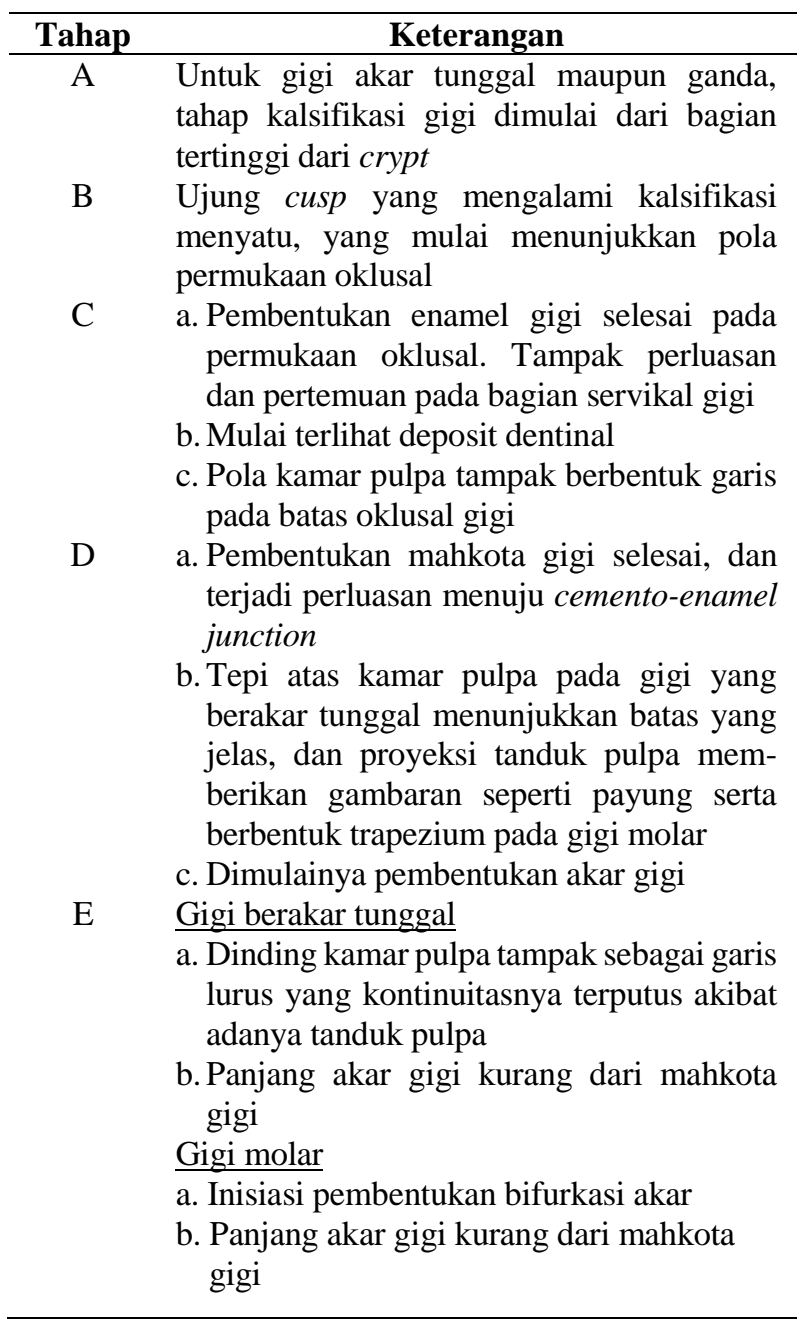

F $\quad$ Gigi berakar tunggal

a. Dinding kamar pulpa tampak menyerupai segitiga sama kaki, dan ujung akar seperti corong

b. Panjang akar gigi sama atau lebih panjang dari tinggi mahkota gigi

Gigi molar

a. Kalsifikasi pada bifurkasi mengalami perluasan, bentuk akar lebih nyata dan ujung akar tampak seperti corong

b. Panjang akar gigi sama atau lebih panang dari tinggi mahkota

G Dinding saluran akar gigi tampak sejajar namun ujung apikal gigi masih terbuka

$\mathrm{H} \quad$ a. Ujung apikal gigi sudah tertutup

b. Membran periodontal memiliki ketebal-an yang sama di sekitar akar gigi

Tabel 2 memperlihatkan penilaian gigi dari gigi A-H yang dipergunakan untuk mengetahui tahapan pembentukan gigi, kemudian semua skor masing-masing gigi dijumlahkan untuk menghitung skor maturasi.

Tabel 2. Skor maturasi. Sumber:

\begin{tabular}{cc}
\hline Demirijan rating & Skor maturasi \\
\hline 0 & 0 \\
A & 1 \\
B & 2 \\
C & 3 \\
D & 4 \\
E & 5 \\
F & 6 \\
G & 7 \\
H & 8 \\
\hline
\end{tabular}

Hasil pengukuran semua skor untuk masing-masing gigi dijumlah dan skor maturasi dihitung, kemudian skor maturasi dikonversi langsung ke dalam rumus yang berhubungan antara usia kronologis dan simple maturity score (SMS). Rumus perhitungan estimasi usia menurut metode BlenkinTaylor ialah sebagai berikut: ${ }^{6}$

Laki-laki:

$\mathrm{y}=-2.042579201+0.416441557 x-0.009307122 x^{2}$ $+0.000128194 x^{3}$

Perempuan:

$\mathrm{y}=-1.914675804+0.421823224 x-0.010273636 x$ $+0.000141442 x^{3}$

Keterangan:

$\mathrm{y}=$ Usia biologis

$\mathrm{x}=$ Skor maturasi 
Hasil perhitungan dari 3 operator dirataratakan kemudian dicatat sebagai usia biologis.

\section{HASIL PENELITIAN}

Tabel 3 memperlihatkan bahwa rerata usia biologis ialah 9,45 tahun dan rerata usia kronologis 9,77 tahun, sehingga didapatkan perbedaan usia sebesar 0,32 tahun dengan menerapkan metode Blenkin-Taylor.

Tabel 3. Hasil uji statistik deskriptif usia biologis dan usia kronologis

\begin{tabular}{lcc}
\hline \multicolumn{1}{c}{ Usia } & Rerata (th) & $\begin{array}{c}\text { Std. } \\
\text { Deviasi }\end{array}$ \\
\hline Usia biologis & 9.45 & \pm 2.93 \\
Usia kronologis & 9.77 & \pm 3.00 \\
Selisih & 0.32 & \pm 0.07 \\
\hline
\end{tabular}

Tabel 4 memperlihatkan bahwa pada laki-laki didapatkan rerata usia kronologis sebesar 9,54 tahun, rerata usia biologis 9,16 tahun, dan perbedaan usia 0,38 tahun dengan 76 sampel radiograf panoramik. Pada perempuan didapatkan rerata usia kronologis sebesar 10 tahun, rerata usia biologis 9,75 tahun, dan perbedaan usia 0,25 tahun dengan 76 sampel radiograf panoramik.

Gambar 1 memperlihatkan ketepatan estimasi data dengan estimasi tepat tanpa selisih usia (on estimation) sebanyak $16 \%$.

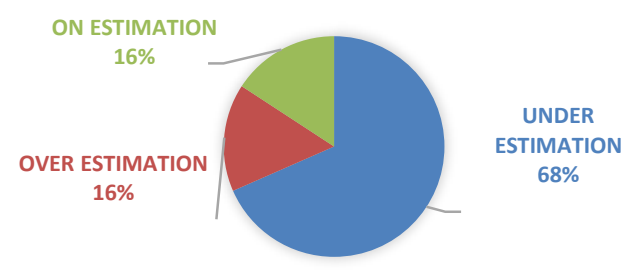

Gambar 1. Hasil uji statistik deskriptif overestimation dan underestimation
Estimasi usia dengan selisih usia biologis lebih besar dari usia kronologis (overestimation) sebanyak 16\%, sedangkan estimasi usia dengan selisih usia biologis lebih kecil dari usia kronologis (undeestimation) sebanyak $68 \%$.

\section{BAHASAN}

Metode Blenkin-Taylor merupakan metode tentang estimasi usia biologis berdasarkan pengukuran gigi untuk mengetahui tahapan pembentukan gigi. ${ }^{6}$ Penelitian ini diukur dengan menggunakan file digital radiograf panoramik dari anak berusia 5-15 tahun. Hasil penelitian ini menunjukkan bahwa terdapat selisih usia sebesar 0,32 tahun pada 152 sampel file digital radiograf panoramik. Selisih usia tersebut merupakan hasil dari underestimation dan overestimation yang biasa terjadi dalam mengestimasi usia. Penelitian lain yang dilakukan oleh Blenkin dan Taylor (2012) mendapatkan perbedaan usia sebesar 0,6 tahun pada populasi Australia dengan 204 sampel. Hal ini dapat disebabkan karena faktor ras, lingkungan, sosioekonomi, dan nutrisi. ${ }^{7}$

Perbedaan ras dapat menyebabkan perbedaan waktu serta urutan erupsi gigi-geligi. Waktu erupsi ras mongoloid lebih cepat daripada orang Eropa maupun campuran Amerika-Eropa. Indonesia termasuk dalam ras mongoloid, sedangkan Australia termasuk dalam ras australoid. Ras mongoloid biasa disebut "orang berkulit kuning" memiliki anatomi akar yang lebih pendek, terdapat perluasan enamel ke bifurkasi akar, pada rahang bawah dengan ukuran gigi insisivus dan kaninus besar, premolar kecil, serta molar besar. Ras Australoid memiliki ukuran rahang besar, diikuti ukuran gigi besar. Gigi molar berukuran paling besar dari ras-ras lainnya, ukuran premolar besar,

Tabel 4. Hasil uji statistik deskriptif pengelompokan jenis kelamin

\begin{tabular}{|c|c|c|c|c|c|}
\hline & \multicolumn{2}{|c|}{ Usia kronologis } & \multicolumn{2}{|c|}{ Usia biologis } & \multirow{2}{*}{$\begin{array}{l}\text { Selisih rerata } \\
\text { (th) }\end{array}$} \\
\hline & $\begin{array}{l}\text { Rerata } \\
\text { (th) }\end{array}$ & $\begin{array}{c}\text { Std. } \\
\text { Deviasi }\end{array}$ & $\begin{array}{l}\text { Rerata } \\
\text { (th) }\end{array}$ & $\begin{array}{c}\text { Std. } \\
\text { Deviasi }\end{array}$ & \\
\hline Laki-laki & 9,54 & $\pm 2,859$ & 9,16 & $\pm 2,858$ & 0,38 \\
\hline Perempuan & 10,0 & $\pm 3,145$ & 9,75 & $\pm 2,984$ & 0,25 \\
\hline
\end{tabular}


serta ukuran gigi anterior yang relatif kecil. ${ }^{8}$

Faktor lingkungan antara lain sosioekonomi dan nutrisi. Tingkat sosioekonomi mampu memengaruhi derajat pengetahuan, gaya hidup, akses terhadap informasi serta pelayanan kesehatan gigi serta mulut. Anak yang tingkat sosioekonominya tinggi mampu memperoleh pelayanan kesehatan serta nutrisi yang lebih baik sehingga pembentukan benih gigi dapat terjadi lebih awal. ${ }^{9}$

Asupan nutrisi dan status gizi pada anak merupakan salah satu faktor yang dapat berdampak pada erupsi gigi permanen. Anak dengan status gizi yang baik mencerminkan terpenuhinya asupan gizi yang seimbang sehingga mempunyai kesehatan umum yang baik, dikarenakan terpenuhinya zat gizi yang baik seperti karbohidrat, kalsium, protein, mineral, dan vitamin. Asupan kalsium, fosfor, vitamin C serta D sangat penting dalam pembentukan struktur gigi. Kekurangan unsur mineral dan vitamin ini dapat menghambat pertumbuhan dan perkembangan gigi, serta memperlambat waktu erupsi gigi. ${ }^{10}$

Pada penelitian ini terdapat masingmasing sejumlah 76 sampel laki-laki dan perempuan. Terdapat selisih usia biologis dan kronologis yaitu sebesar 0,38 tahun untuk laki-laki dan perbedaan usia 0,25 tahun pada perempuan. Hal ini menunjukkan bahwa metode Blenkin-Taylor memperkirakan usia biologis yang lebih muda dari usia kronologisnya. Hasil penelitian oleh Mohammed et al ${ }^{11}$ menunjukkan underestimation dengan rerata usia laki-laki 0,8 tahun dan rerata usia perempuan 0,5 tahun yang menggunakan metode Willems. Penelitian tersebut dilakukan pada populasi Belgia-Kaukasoid yang berusia 6-16 tahun dengan jumlah sampel laki-laki 166 orang dan perempuan 166 orang. Hal ini disebabkan karena waktu maturasi pada perempuan lebih cepat dibanding laki-laki, sehingga waktu erupsi gigi pada anak perempuan lebih cepat daripada anak laki-laki.

Beberapa faktor dapat memengaruhi waktu erupsi gigi, yaitu keadaan oral hygiene index $(\mathrm{OHI})$ dari pasien, faktor nutrisi, dan ekstraksi. Keadaan OHI pasien yang buruk dapat mengakibatkan infeksi jaringan periodontal, sehingga pertumbuhan dan perkembangan gigi terhambat. Erupsi gigi geligi yang terlalu awal (premature eruption) terbentuk karena pada gigi desidui yang tergantikan terjadi karies parah yang merusak tulang koronal gigi geligi pengganti, yang berdampak gigi geligi erupsi terlalu awal walaupun akar baru terbentuk $<50 \%{ }^{12}$

Hasil estimasi usia Blenkin-Taylor pada Gambar 1 menunjukkan on estimation sebesar $16 \%$, estimasi tidak sesuai sebesar $84 \%$ yang terdiri dari underestimation $68 \%$ dan overestimation $16 \%$. Pada penelitian ini, underestimation menunjukkan selisih rerata usia biologis sekitar 2-5 bulan di bawah usia kronologis, sedangkan overestimation menunjukkan selisih rerata usia biologis sekitar 0,17-2 tahun di atas usia kronologis, sehingga selisih usia biologis dan usia kronologis pada metode Blenkin-Taylor lebih baik daripada metode estimasi usia lainnya. Penelitian oleh Esan et $\mathrm{al}^{13}$ melaporkan hasil yang serupa saat menggunakan metode Demirjian dan metode Willems. Adanya underestimation maupun overestimation dalam penelitian estimasi usia dipengaruhi oleh faktor genetik, lingkungan, nutrisi, serta besar populasi. ${ }^{13}$

Berbeda halnya dengan penelitian oleh Kiran et al ${ }^{14}$ terhadap 130 laki-laki dan 120 perempuan di India dengan menggunakan metode Demirjian. Hasil penelitian tersebut mendapatkan overestimation 1,72 tahun untuk laki-laki dan 1,91 tahun pada perempuan. Metode Blenkin-Taylor dimodifikasi dari metode Demirjian. Perbedaan hasil ini disebabkan oleh perhitungan yang menggunakan rumus regresi berbeda karena metode Demirjian mengalami modifikasi perhitungan pada beberapa ras. Modifikasi dapat dilakukan kembali pada rumus regresi sehingga diperoleh usia biologis yang lebih mendekati usia kronologis.

Sampel gigi menggunakan metode Blenkin-Taylor modifikasi Demirjian yaitu tujuh gigi geligi dari gigi insisivus pertama sampai gigi molar kedua rahang bawah region kanan. Penelitian oleh Kiran et $\mathrm{al}^{14}$ dan Archarya ${ }^{15}$ menggunakan delapan gigi geligi dari gigi insisivus pertama hingga gigi molar rahang bawah region kiri. Hasil kedua 
penelitian tersebut menunjukkan bahwa metode Blenkin-Taylor dapat diaplikasikan di Indonesia, khususnya pada usia anak 5-15 tahun, dengan penyesuaian pada rumus perhitungan estimasi usia sesuai kurva regresi ras. ${ }^{14,15}$

Kendala dalam penelitian ini yaitu kesulitan memperoleh radiograf dengan kualitas mutu radiograf panoramik yang baik atau excellent. Kontras yang kurang baik menyulitkan peneliti untuk melakukan penilaian pada apeks gigi. Interpretasi dari kualitas mutu radiograf dipengaruhi faktor kontras, densitas, resolusi, serta distorsi. Kontras dilihat dari perbedaan radioopak dan radiolusen pada foto radiograf panoramik dengan memberikan kriteria penilaian excellent/sempurna yang berarti tidak ada kesalahan; diagnostically acceptable yang berarti terdapat beberapa kesalahan tetapi dapat diterima untuk menentukan diagnosis; diagnostically unacceptable yang berarti tidak dapat diterima dalam menentukan diagnosis. Kontras yang tidak baik akan memengaruhi hasil interpretasi foto radiograf yaitu objek yang diamati tidak terlihat dengan jelas, sehingga menyebabkan diagnosis yang kurang tepat. ${ }^{16}$

\section{SIMPULAN}

Selisih rerata antara usia kronologis dan usia biologis menggunakan metode BlenkinTaylor di Kota Semarang yaitu sebesar $\pm 0,32$ tahun pada individu usia 5-15 tahun.

\section{Ucapan Terima Kasih}

Ucapan terima kasih ditujukan kepada semua pihak yang telah memberikan saran dan masukan dalam studi ini.

\section{Konflik Kepentingan}

Penulis menyatakan tidak terdapat konflik kepentingan dalam studi ini

\section{DAFTAR PUSTAKA}

1. Nandiasa SR, Bramma K, Mindya Y Penggunaan radiograf gigi untuk kepentingan identifikasi forensik. J Od Dent. 2016;3(1):74-7.

2. Panchbhai AS. Dental radiographic indicators, a key to age estimation, Dentomaxillofac
Rad. 2011;40(4):199-212.

3. Trisnowahyuni, Rahim AH, Doloksaribu EI. Rekam medis odontogram sebagai alat identifikasi dan kepentingan pembuktian di pengadilan. SOEPRA J Hukum Kes. 2018;3(1):117-31.

4. George GJ, Chatra L, Shenoy P, Km V, Prabhu RV, Kumar LSV. Age determination by Schour Massler Methode. Int J For Od. 2017;3(1):38-42.

5. Rusydiana F, Oscandar F, Sam B. Identifikasi usia berdasarkan metode Al Qahtani melalui radiograf panoramik di RSGM FKG UNPAD. J Ked Gi Unpad. 2016; 28(3):166-71.

6. Blenkin MRB, Evans W. Age estimation from the teeth using a modified Demirjian system. J Forensic Sci, 2010;55(6): 1504-8.

7. Blenkin M, Taylor J. Age estimation charts for a modern Australian population. Forensic Sci Int. 2012;221(1-3):106-2.

8. Rawlani SM, Rawlani SS, Bhowate RR, Chandak RM, Khubchandani M. Racial characteristics of human teeth. Int J For Odonto. 2017;2(1):38-42.

9. Almonaitiene R, Balciuniene I, Tutkuviene J. Factors influencing permanent teeth eruption. Stomatologija, Baltic Dental and Maxillofacial Journal. 2010;12(3): 67-72.

10. Rahmawati AD, Retriasih H, Medawati A. Hubungan antara status gizi dengan status erupsi gigi insisivus sentralis permanen mandibula. IDJ. 2014;3(1): 16-20.

11. Mohammed RB, Krishnamraju PV, Jyotsna. Dental age estimation Willems method: A digital orthopantomographic study, Contemp Clin Dent, 2014;5 (3):371-6.

12. Kuswandari S. Maturasi dan erupsi gigi permanen pada anak periode gigi pergantian (The maturition and eruption of permanent teeth in mixed dentition children). Dental Journal (Majalah Kedokteran Gigi). 2014;47(2):72.

13. Esan TA, Yengopal V, Schepartz LA. The Demirjian versus the Willems method for dental age estimation in different populations: a meta-analysis of published studies. PLoS ONE. 2017;12(11):23

14. Kiran CH, Reddy RS, Ramesh T, Madhavi N, Ramya K. Radiographic evaluation of dental ge using Demirjian's eight-teeth method and its comparasion with Indian 
formulas in South Indian Population. J For Dent Sci, 2015;7(1):44-8.

15. Archarya AB. Age estimation in India using Demirjian's 8-teeth method. J Forensic
Sci. 2011;56:124-7.

16. Supriyadi. Pedoman interpretasi radiograf lesilesi di rongga mulut. Stomatognatic, 2012;9(3):134-9. 